\title{
Quercetin synergistically reactivates human immunodeficiency virus type 1 latency by activating nuclear factor- $\mathrm{B}$
}

\author{
XINYI YANG, XIAOLI ZHU, HAIYAN JI, JUNXIAO DENG, PANPAN LU, ZHENGTAO JIANG, \\ XIAN LI, YIBO WANG, CHUQIAO WANG, JINGYA ZHAO, YANAN WANG, \\ YANGCHENG ZHONG, HE YANG and HUANZHANG ZHU
}

State Key Laboratory of Genetic Engineering, Institute of Genetics, School of Life Sciences, Fudan University, Shanghai 200433, P.R. China

Received March 31, 2016; Accepted March 16, 2017

DOI: $10.3892 / \mathrm{mmr} .2017 .8188$

\begin{abstract}
Highly active antiretroviral therapy (HAART) is very effective in suppressing human immunodeficiency virus type 1 (HIV-1) replication. However, the treatment is required to be administered for the remainder of an individual's lifetime due to latent HIV-1 reservoirs. The 'shock-and-kill' strategy, which involves using agents to reactivate latent HIV-1 and subsequently killing latently infected cells in the presence of HAART, was recently proposed. Unfortunately, no agents have currently demonstrated an ability to reactivate latent HIV-1 in vivo in the absence of toxicity. Therefore, the identification of novel latency activators is required. In order to identify a potential novel agent, the present study investigated the effect of quercetin on latent HIV-1 reactivation using an established model of HIV-1 latency. As a marker for reactivation of HIV-1 in C11 Jurkat cells, the expression of green fluorescent protein, controlled by HIV-1 long terminal repeat, was observed by fluorescence microscopy. The results of the present study demonstrated that quercetin effectively reactivated latent HIV-1 gene expression alone, and led to synergistic reactivation when combined with prostratin or valproic acid. In addition, the present study provides evidence that quercetin may reactivate $\mathrm{HIV}-1$ expression by inducing nuclear factor- $\kappa \mathrm{B}$ nuclear translocation, and that the toxicity of quercetin is lower when compared with various additional activators of HIV-1. Combined, the results of the present study indicate that quercetin may be an effective agent to disrupt HIV-1 latency and may be useful in future eradication strategies.
\end{abstract}

Correspondence to: Professor Huanzhang Zhu, State Key Laboratory of Genetic Engineering, Institute of Genetics, School of Life Sciences, Fudan University, 2005 Songhu Road, Shanghai 200433, P.R. China

E-mail: hzzhu@fudan.edu.cn

Key words: quercetin, human immunodeficiency virus type 1 latency, synergistic reactivation, nuclear factor- $\mathrm{B}$ transcription factor

\section{Introduction}

Although highly active antiretroviral therapy (HAART) has been proven to suppress human immunodeficiency virus type 1 (HIV-1) replication to undetectable levels, interrupting HAART allows the virus to rapidly increase in numbers when compared with pretreatment levels $(1,2)$. Previous studies have demonstrated that latently infected cells are major obstacles to treatment success, and these cells are not eliminated by HAART (3-5). In addition, previous studies have demonstrated that the estimated size of this latent reservoir is $10^{5}-10^{6}$ cells/patient $(6,7)$. It has been proposed that, for the complete eradication of HIV-1, patients would be required to receive HAART for $>70$ years $(6,7)$. However, this therapy is expensive and associated with toxic effects. For these reasons, elimination of the latent reservoir of HIV-1 is an important aim.

Although the mechanisms that establish and maintain HIV-1 latency are not well defined, specific factors may contribute to HIV-1 latency, including activator protein-1 (AP-1), nuclear factor of activated T-cells (NFAT), nuclear factor- $\kappa \mathrm{B}(\mathrm{NF}-\kappa \mathrm{B})$ and specificity protein 1 (SP1) (8). In addition, in latently infected cells, various studies have demonstrated that the genomes of HIV-1 are present within genes that are actively transcribed $(9,10)$. Therefore, transcriptional interference of the host gene may contribute to viral latency (9-11). In addition, histone deacetylation, DNA methylation, histone methylation and additional specific epigenetic modifications may silence HIV-1 transcription and expression (12).

To eradicate latent HIV-1 infection, the 'shock and kill' strategy was proposed, which involves reactivation of latent HIV-1 expression by various agents followed by the killing of infectious cells by additional methods (13). Numerous potential agents that may reactivate latent HIV-1 infection have been identified, and the agents that have been investigated with regards to eradication of latent HIV-1 are divided into the following seven groups: Histone deacetylase inhibitors, including suberoylanilide hydroxamic acid/vorinostat (14), valproic acid (VPA) (15), suneroyl bis-hydroxamic (16), panobinostat, givinostat, belinostat (17) and M344 (18); cytokines and chemokines, including tumor necrosis factor $\alpha$ (TNF- $\alpha$ ) (19) and $\mathrm{NF}-\kappa \mathrm{B}$ (20); DNA methyltransferase inhibitors, which 
primarily include decitabine (2'-deoxy-5-azacytidine) and its analogs (21); histone methyltransferase inhibitors, such as BIX01294 (22); protein kinase C activators such as prostratin (23); positive transcription elongation factor $\mathrm{b}$ activators, which include hexamethylene bisacetamide (24); and particular unclassified agents, such as disulfiram (25). However, due to limitations of effectiveness and toxicity, the agents may not be suitable when administered alone. Therefore, an increasing number of studies have focused on identifying a cocktail of agents that reactivate latent HIV-1 infections. Ideally, agents or agent cocktails used to eradicate latent reservoirs should be highly efficient at reactivating latent HIV-1, not induce global T-cell activation, and must exhibit acceptable pharmacological and toxicological properties. To the best of the author's knowledge, no agents that effectively disrupt HIV-1 latency and exhibit low toxicities have been identified thus far. Therefore, the identification of novel agents, and particular agent combinations is required.

Quercetin is a flavonol that is present in various plant-based foods, including onions, apples, citrus fruits, berries, red grapes, red wine, broccoli, tea, flowers and bark roots (26). It has been used as a treatment for various conditions, including allergies, asthma, bacterial infections, arthritis, gout, eye disorders, hypertension and neurodegenerative disorders (26). Previous studies have indicated that quercetin may potentially inhibit the HIV-1 integrase and reverse transcriptase enzymes $(27,28)$; however, limited information regarding the role of quercetin in combating latent HIV-1 infections is known. Therefore, the present study aimed to investigate the ability of quercetin to reactivate latent HIV-1. To achieve this, the ability of quercetin to induce HIV-1 expression in latently infected cells, as well as the potential underlying molecular mechanisms, were investigated. In addition, the effect of quercetin in combination with additional activators was investigated. The results demonstrated that quercetin reactivated latent HIV-1 in an in vitro model of HIV-1 latency potentially via the NF- $\mathrm{KB}$ signaling pathway, and synergistically reactivated HIV-1 latency when combined with VPA or prostratin. The results indicated that either of these combinations may be useful as a potential anti-latency therapy.

\section{Materials and methods}

Cell culture and chemical treatment. C11 cells, a type of latently infected Jurkat cell, were generated in our laboratory (Shanghai, China) and have been employed in previous studies (29-31). Briefly, cells were transfected with a construct (donated by the National Institutes of Health, Bethesda, MD, USA) that encodes green fluorescent protein (GFP) as a marker for Tat-driven HIV-1 long terminal repeat (LTR) expression; lentiviral transfection was performed as previously described (32). The C11 cells were cultured in RPMI-1640 medium (Corning Incorporated, Corning, NY, USA) supplemented with $10 \%$ fetal bovine serum (FBS; Gibco; Thermo Fisher Scientific, Inc., Waltham, MA, USA), 100 U/ml penicillin and $100 \mu \mathrm{g} / \mathrm{ml}$ streptomycin (Invitrogen; Thermo Fisher Scientific, Inc.) at $37^{\circ} \mathrm{C}$ and $5 \% \mathrm{CO}_{2}$. The HEK $293 \mathrm{~T}$ human endothelial kidney cell line was purchased from the American Type Culture Collection (Manassas, VA, USA), and cells were cultured in Dulbecco's modified Eagle's medium (Gibco;
Thermo Fisher Scientific, Inc.) with 10\% FBS, $100 \mathrm{U} / \mathrm{ml}$ penicillin and $100 \mu \mathrm{g} / \mathrm{ml}$ of streptomycin at $37^{\circ} \mathrm{C}$ and $5 \%$ $\mathrm{CO}_{2}$. Quercetin was purchased from Sigma-Aldrich; Merck KGaA (Darmstadt, Germany) and VPA was purchased from InvivoGen (San Diego, CA, USA). Prostratin was purchased from LC Laboratories (Woburn, MA, USA). Recombinant human TNF- $\alpha$ was purchased from EMD Millipore (Billerica, MA, USA). Quercetin (100 mM), TNF- $\alpha$ (1 mg/ml), VPA $(100 \mathrm{mM})$ and prostratin $(10 \mathrm{mM})$ were dissolved in anhydrous dimethylsulfoxide and stored at $-20^{\circ} \mathrm{C}$.

Visualization of GFP. As GFP was used as the marker of HIV-1 expression, the expression of GFP was observed by fluorescence microscopy to confirm reactivation. C11 cells $\left(3 \times 10^{4}\right)$ were treated at $37^{\circ} \mathrm{C}$ and $5 \% \mathrm{CO}_{2}$ with quercetin $(20 \mu \mathrm{M})$ or mock $(0 \mu \mathrm{M}), \mathrm{C} 11$ cells $\left(6 \times 10^{4}\right)$ were subsequently viewed using a Nikon fluorescence microscope (Nikon Corporation, Tokyo, Japan). All microscope samples were imaged across 10 random fields using a Nikon E2 digital camera (Nikon Corporation), and images were analyzed using EIS Element F 3.0 (Nikon Corporation).

Flow cytometry. $\mathrm{C} 11$ cells $\left(6 \times 10^{4}\right)$ were washed with phosphate-buffered saline (PBS) and incubated with the following treatments: Quercetin $(20 \mu \mathrm{M})$ or mock treatment for $72 \mathrm{~h}$; quercetin $(20 \mu \mathrm{M})$ or mock treatment for $0,24,48,72$ and $96 \mathrm{~h}$; quercetin $(5,10,20$ and $40 \mu \mathrm{M})$ or mock treatment for $72 \mathrm{~h}$; quercetin $(20 \mu \mathrm{M})$, mock $(0 \mu \mathrm{M})$ treatment, VPA $(2 \mathrm{mM})$, prostratin $(200 \mathrm{nM})$, quercetin $(20 \mu \mathrm{M})+\mathrm{VPA}(2 \mathrm{mM})$ and quercetin $(20 \mu \mathrm{M})+$ prostratin $(200 \mathrm{nM})$ for $72 \mathrm{~h}$. Cells were cultured in RPMI-1640 medium supplemented with 10\% FBS, $100 \mathrm{U} / \mathrm{ml}$ penicillin and $100 \mu \mathrm{g} / \mathrm{ml}$ streptomycin, at $37^{\circ} \mathrm{C}$ and $5 \% \mathrm{CO}_{2}$. Cells were washed with $1 \mathrm{ml} \mathrm{PBS}$ for $5 \mathrm{~min}$ and resuspended in $300 \mu \mathrm{l}$ PBS. GFP expression was measured using a FACScan flow cytometer (BD Biosciences, Franklin lakes, NJ, USA), and FACS data were analyzed with FlowJo software version 10.0 (FlowJo LLC, Inc., Ashland, OR, USA). GFP-associated fluorescence was differentiated from background fluorescence by the gating of live cells $(10,000$ events in total) and by two-parameter analysis. For all analyses, three independent experiments were performed, and samples were analyzed in triplicate.

Cytotoxicity assay. Cell proliferation and viability were measured using a Cell Counting Kit-8 assay (CCK-8; Dojindo Molecular Technologies, Inc., Rockville, MD, USA) (30,33). C11 cells were seeded in 96-well plates $\left(\sim 4 \times 10^{4}\right.$ cells per well $)$ before they were treated with $0,5,10,20,40,80$ and $160 \mu \mathrm{M}$ quercetin for $48 \mathrm{~h}$ at $37^{\circ} \mathrm{C}$ and $5 \% \mathrm{CO}_{2}$. This was followed by the addition of $10 \mu \mathrm{l}$ CCK- 8 solution to each well of the plate. Following incubation for $4 \mathrm{~h}$ at $37^{\circ} \mathrm{C}$, the absorbance was read at $450 \mathrm{~nm}$ using a microplate reader. For each sample, the half maximal inhibitory concentration $\left(\mathrm{IC}_{50}\right)$ was measured in triplicate and at least three independent assays were performed.

Transient transfection and luciferase assays. HEK 293T cells were plated at $1 \times 10^{5}$ cells/well in 24 -well plates at $24 \mathrm{~h}$ prior to transfection, and were transfected using Lipofectamine ${ }^{\circledR} 2000$ according to the manufacturer's protocol (Invitrogen; Thermo Fisher Scientific, Inc.). The HIV-1 LTR-luc (1.0 $\mu \mathrm{g}$; 
donated by Dr Warner C. Greene, Duke University Medical Center, Durham, NC, USA) (34), HIV-1 LTR lacking two $\kappa \mathrm{B}$ enhancers [1.0 $\mu \mathrm{g}$; HIV-1-LTR $(\Delta \kappa \mathrm{B})$-luc], HIV-1 LTR lacking an AP-1 enhancer [1.0 $\mu \mathrm{g}$; HIV-1-LTR ( $\Delta \mathrm{AP}-1)-$ luc], HIV-1 LTR lacking an SP1 enhancer [1.0 $\mu \mathrm{g}$; HIV-1-LTR ( $\triangle \mathrm{SP} 1)$-luc; all donated by Dr Andrew D. Badley (Division of Infectious Diseases, Mayo Clinic, Rochester, MN, USA) (35) or pRL-SV40 (0.1 $\mu \mathrm{g}$; Promega Corp., Madison, WI, USA) vector constructs were formulated into liposomes and transfected into HEK 293 T cells. At 24 h post-transfection, the cells were mock $(0 \mu \mathrm{M})$-treated, or treated with quercetin $(20 \mu \mathrm{M})$ or TNF- $\alpha(10 \mathrm{ng} / \mathrm{ml})$ at $37^{\circ} \mathrm{C}$ and $5 \% \mathrm{CO}_{2}$. At $48 \mathrm{~h}$ post-treatment, cells were lysed with passive buffer (Yeasen Co., Ltd., Shanghai, China) and the luciferase activity was measured using a Dual-Luciferase ${ }^{\circledR}$ Reporter assay kit (Promega Corp.) and normalized by Renilla luciferase activity, according to the manufacturer's instructions.

Cell nuclear protein extraction and electrophoretic mobility shift assay (EMSA). Nuclear extracts from C11 cells following treatment with different agents were obtained as previously described $(30,36)$. Briefly, C11 cells $\left(3 \times 10^{4}\right)$ were treated with quercetin $(10,20$ and $40 \mu \mathrm{M})$ for $3 \mathrm{~h}$ or TNF- $\alpha(10 \mathrm{ng} / \mathrm{ml})$ for $30 \mathrm{~min}$, before they were washed twice with PBS and resuspended in $100 \mu \mathrm{l}$ ice-cold buffer A [10 mM HEPES-NaOH, $\mathrm{pH} 7.9 ; 10 \mathrm{mM} \mathrm{KCl} ; 1.5 \mathrm{mM} \mathrm{MgCl} ; 0.5 \mathrm{mM}$ dithiothreitol (DTT); and $0.2 \mathrm{mM}$ phenylmethane sulfonyl fluoride (PMSF)] and $0.6 \%$ nonidet P-40 for $15 \mathrm{~min}$ followed by centrifugation at $15,000 \mathrm{x} g$ for $2 \mathrm{~min}$ at $4^{\circ} \mathrm{C}$. The supernatant contained cytoplasmic protein, and was discarded. The precipitated nuclear pellet was washed once with buffer A and resuspended in $60 \mu \mathrm{l}$ ice-cold buffer B (20 mM HEPES-NaOH, pH 7.9; $420 \mathrm{mM}$ $\mathrm{NaCl} ; 1.5 \mathrm{mM} \mathrm{MgCl} 2 ; 0.2 \mathrm{mM}$ EDTA; $0.5 \mathrm{mM}$ DTT; $0.2 \mathrm{mM}$ PMSF; $25 \%$ glycerol). The mixture was incubated on ice for 30 min with intermittent mixing followed by centrifugation at $15,000 \mathrm{x} \mathrm{g}$ for $15 \mathrm{~min}$ at $4^{\circ} \mathrm{C}$. The supernatant, containing nuclear proteins, was collected and the protein concentration was measured with a bicinchoninic acid kit (Beyotime Institute of Biotechnology, Haimen, China). Proteins were stored at $-80^{\circ} \mathrm{C}$ for EMSA analysis.

The EMSA for NF- $\kappa$ B was performed using the LightShift $^{\mathrm{TM}}$ Chemiluminescent EMSA kit (Pierce; Thermo Fisher Scientific, Inc.) according to the manufacturer's protocol. Briefly, $10 \mu \mathrm{M}$ biotin-labeled double-stranded NF- $\mathrm{BB}$ oligonucleotides (5'-AGTTGAGGGGACTTTCCCAGG-3' and 3'-TCAACTCCCCTGAAAGGGTCC-5') (Shanghai Ruidi Biological Technology Co., Ltd., Shanghai, China) were incubated with $20 \mu \mathrm{g}$ nuclear protein extracts at room temperature for $20 \mathrm{~min}$. The samples were subsequently subjected to $5 \%$ non-denaturing polyacrylamide gel electrophoresis in Tris/borate/EDTA buffer and transferred to a nylon membrane. After attaching to the membrane by UV-crosslinking, the DNA-protein complexes were detected by LightShift ${ }^{\mathrm{TM}}$ chemiluminescence and analyzed by autoradiography. Cold competition was performed in the presence of 100 -fold excess non-labeled consensus oligonucleotides for $10 \mathrm{~min}$ prior to the addition of labeled oligonucleotides.

Statistical analysis. Data are representative of three independent experiments. Values were presented as the mean \pm standard deviation. One-way analysis of variance and Tukey's post hoc test were performed using SPSS version 19.0 (IBM SPSS, Armonk, NY, USA). P<0.05 was considered to indicate a significant difference.

\section{Results}

Quercetin reactivates latent $H I V-1$ replication. In order to assess the induction of HIV-1 expression in latently infected cells by quercetin, C11 cells that were established in our lab were employed. These cells are Jurkat $\mathrm{T}$ cells latently infected with a single provirus integrated into intron 3 of the RNA binding protein with serine rich domain 1 gene, combined with a GFP gene and under the control of the HIV-1 LTR, and was used as a marker of HIV-1 LTR expression (31). The structure of quercetin is presented in Fig. 1A. Quercetin $(20 \mu \mathrm{M})$ was used to treat $\mathrm{C} 11$ cells for $72 \mathrm{~h}$, and fluorescence microscopy analysis indicated $\sim 10 \% \mathrm{C} 11$ cells were positive for HIV-1 LTR expression (Fig. 1B). Subsequently, as GFP was used as a marker of HIV-1 expression, flow cytometry was performed to detect the percentage of GFP-positive cells (Fig. 1C). The results indicated that the HIV-1 transcriptional activity increased to $14.50 \%$ following treatment with quercetin $(20 \mu \mathrm{M})$ for $72 \mathrm{~h}$, compared with $3.12 \%$ in mock-treated cells. To analyze the kinetics of HIV-1 LTR expression induced by quercetin, a kinetics experiment was performed where quercetin $(20 \mu \mathrm{M})$ or mock-treated $\mathrm{C} 11$ cells were cultured for 1-4 days. At each time point, flow cytometry analysis was performed to determine the proportion of GFP-expressing cells. Following treatment with quercetin, the percentage of GFP-expressing cells increased for the first 3 days and then plateaued at day 4, whereas no increase in GFP-positive cells was observed in the mock-treated group over the same time period (Fig. 2A). These results indicated that quercetin may affect HIV-1 expression in a time-dependent manner. To determine the effect of increasing concentrations of quercetin on HIV-1 production, cells were treated with 5, 10, 20 and $40 \mu \mathrm{M}$ quercetin for $72 \mathrm{~h}$. The percentage of GFP-expressing cells was increased by between 3 - and 6 -fold compared with the mock-treated cells (Fig. 2B). The results demonstrated that quercetin induced HIV-1 LTR reactivation in a concentration-dependent manner.

Quercetin synergistically reactivates latent $H I V-1$ production. As quercetin is effective and less toxic than prostratin (37), the present study assessed whether quercetin synergistically reactivates HIV-1 in C11 cells when combined with VPA or prostratin. $\mathrm{C} 11$ cells were treated with quercetin alone $(20 \mu \mathrm{M})$, VPA alone $(2 \mathrm{mM})$, prostratin alone $(200 \mathrm{nM})$, quercetin $(20 \mu \mathrm{M})+$ VPA $(2 \mathrm{mM}$, quercetin $(20 \mu \mathrm{M})+$ prostratin $(200 \mathrm{nM})$ or received mock treatment for $72 \mathrm{~h}$. A synergistic interaction between two activators indicates that combined treatment results in a level of activation that is higher than the sum of the activation induced by each activator when applied individually (38). As demonstrated in Fig. 3, the percentage of GFP-positive cells was $14.6 \%$ in the quercetin alone $(20 \mu \mathrm{M})$, $11.4 \%$ in VPA alone $(2 \mathrm{mM}), 22.6 \%$ in prostratin alone $(200 \mathrm{nM}), 44.4 \%$ in quercetin + VPA, $53.8 \%$ in quercetin + prostratin and $1.8 \%$ in the mock-treated groups. These results indicate that quercetin, in combination with VPA or prostratin, 
A<smiles>O=Cc1cc(O)c2c(=O)c(O)c(-c3ccc(O)c(O)c3)oc2c1</smiles>

B

Mock

(10X,72 h)

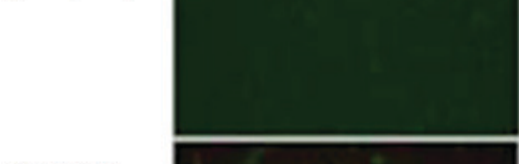

Quercetin

(20 $\mu \mathrm{M}, 10 \mathrm{X}$,

$72 \mathrm{~h})$

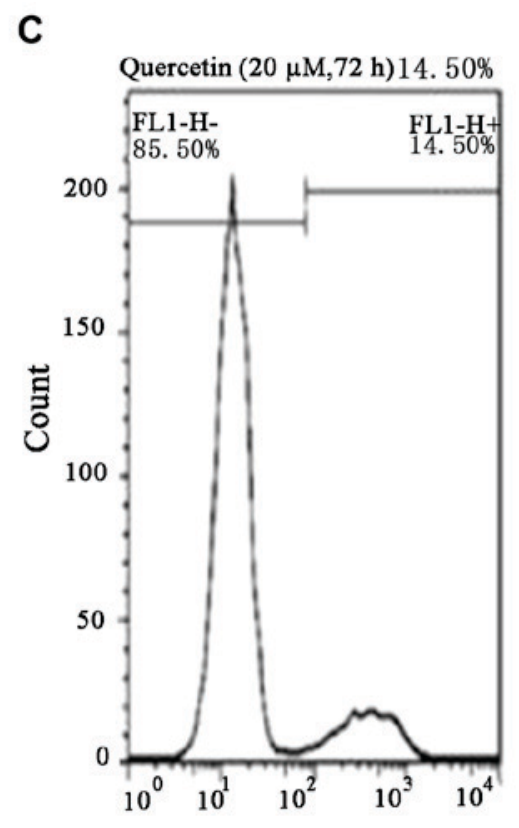

FL1-H

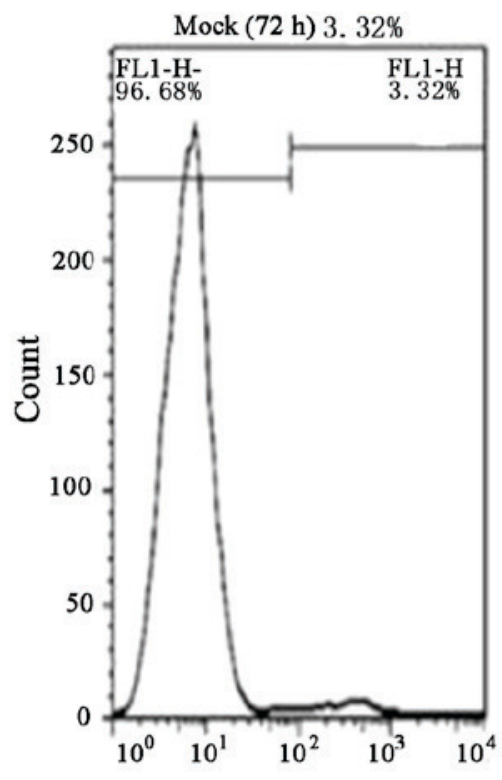

FL1-H

Figure 1. Reactivation of HIV-1 in latently infected C11 cells by quercetin. (A) Molecular structure of quercetin. (B) Fluorescence microscopy analysis of GFP expression in mock- or quercetin $(20 \mu \mathrm{M})$-treated C11 cells following $72 \mathrm{~h}$. (C) C11 cells, which have an integrated GFP construct under the control of the HIV-1 LTR, were treated with $20 \mu \mathrm{M}$ quercetin or received mock treatment for $72 \mathrm{~h}$. The percentage of cells expressing GFP was measured by flow cytometry analysis to provide a measure of HIV-1 expression. HIV-1, human immunodeficiency virus type 1; GFP, green fluorescent protein; LTR, long terminal repeat.
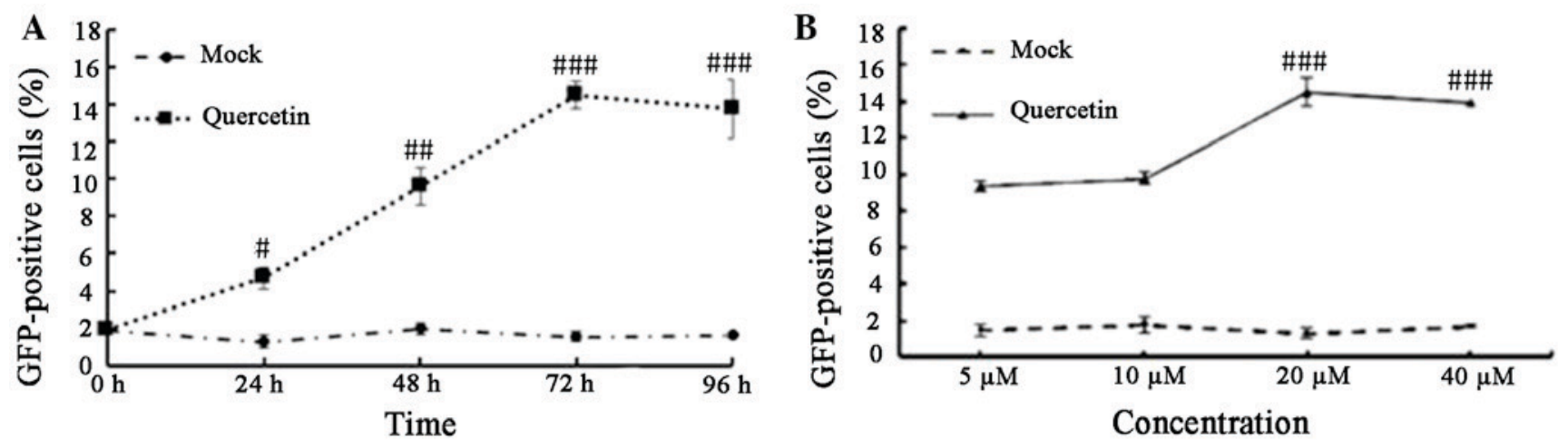

Figure 2. Time- and concentration-dependent effects of quercetin on HIV-1 production. (A) Time-dependent effects of quercetin on HIV-1 production. C11 cells were mock-treated or treated with $20 \mu \mathrm{M}$ quercetin for 0,24, 48, 72 and $96 \mathrm{~h}$ and the percentage of GFP-positive cells was determined by flow cytometry analysis. (B) Concentration-dependent effects of quercetin on HIV-1 production. C11 cells were mock-treated or treated with 0,5 , 1020 or $40 \mu \mathrm{M}$ quercetin for $72 \mathrm{~h}$ and the percentage of GFP-positive cells was determined by flow cytometry analysis. Data are presented as the mean \pm standard deviation of three independent experiments. HIV-1, human immunodeficiency virus type 1 ; GFP, green fluorescent protein ${ }^{\#} \mathrm{P}<0.05$, ${ }^{\# \#} \mathrm{P}<0.01$ and ${ }^{\# \# \#} \mathrm{P}<0.001$ vs. mock-treated cells.

resulted in synergistic reactivation of latent HIV-1 production in $\mathrm{C} 11$ cells

Quercetin exhibits no apparent toxicity in vitro. The toxicity of quercetin was investigated to determine whether it may be ideal therapeutic agent for reactivation of latent HIV-1. C11 cells were treated with $0,5,10,20,40,80$ and $160 \mu \mathrm{M}$ quercetin for $72 \mathrm{~h}$, and cell viability was subsequently analyzed using CCK-8 assay. At its active concentration $(20 \mu \mathrm{M})$, quercetin exhibited no significant toxicity in C11 cells (Fig. 4).

Quercetin activates the HIV-1 LTR through induction of $N F-\kappa B$. The present study subsequently investigated the signaling pathway through which quercetin may mediate activation of the HIV-1 LTR. Binding sites for a number of inducible transcription factors, including NF- $\mathrm{NB}, \mathrm{AP}-1$ and SP1, are located within the HIV-1 LTR (39). To determine the role of particular transcription factors in the activation of the HIV LTR by quercetin, the present study employed HEK 293T cells that were transfected with luciferase reporter plasmids containing the wild-type HIV-1 LTR, LTR lacking two $\kappa \mathrm{B}$ enhancers, LTR lacking AP-1 enhancers or LTR lacking SP1 enhancers. TNF- $\alpha$ was selected as a positive control. Compared with mock controls, TNF- $\alpha$ induced 3.65-fold upregulation of the HIV-1-LTR-luc reporter, $\sim 2.98$-fold upregulation of the HIV-1-LTR ( $\triangle \mathrm{AP}-1)$-luc and 


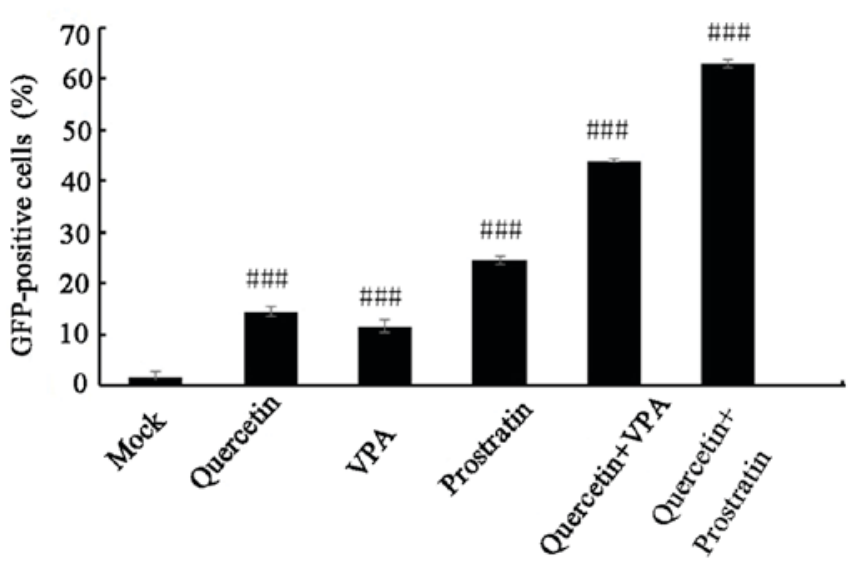

Figure 3. Synergistic activation of HIV-1 in latently infected cells. Synergistic activation of HIV-1 by quercetin in combination with VPA or prostratin in C11 cells. C11 cells were mock-treated or treated with quercetin $(20 \mu \mathrm{M})$, VPA $(2 \mathrm{mM})$, prostratin $(200 \mathrm{nM})$, quercetin + VPA or quercetin + prostratin. The effects of synergistic activation of HIV-1 were determined by quantifying the proportion of GFP-positive cells by flow cytometry analysis following treatment for $72 \mathrm{~h}$. Data are presented as the mean \pm standard deviation of three independent experiments. ${ }^{\# \#} \mathrm{P}<0.001$ vs. mock-treated group. HIV-1, human immunodeficiency virus type 1; VPA, valproic acid; GFP, green fluorescent protein

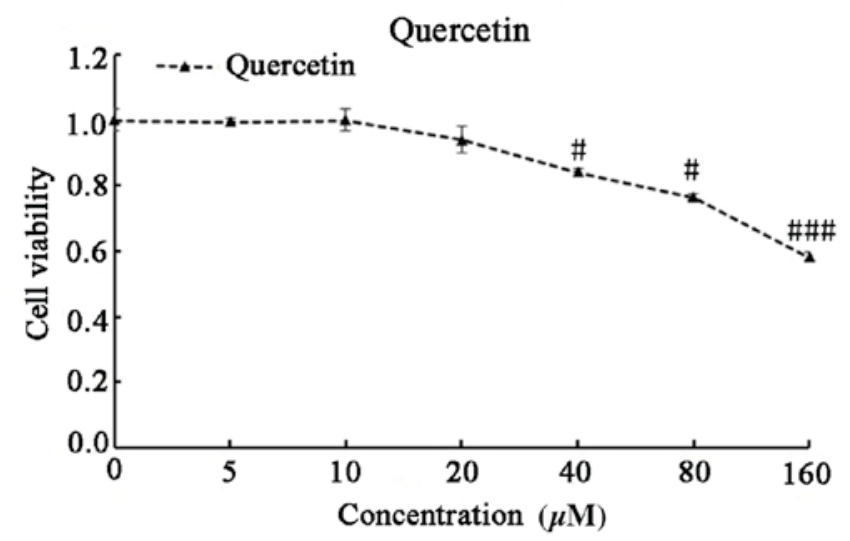

Figure 4. Low levels of toxicity in latently infected cells treated with $20 \mu \mathrm{M}$ quercetin. Effects of quercetin on the viability of C11 cells. C11 cells were treated with $0,5,10,20,40,80$ and $160 \mu \mathrm{M}$ quercetin for $72 \mathrm{~h}$ and cell viability was assessed using the CCK- 8 assay, and optical density was recorded. ${ }^{\#} \mathrm{P}<0.05$ and ${ }^{\# \# \# "} \mathrm{P}<0.001$ vs. mock treated cells.

3.11-fold upregulation of HIV-1-LTR $(\Delta \mathrm{SP} 1)$-luc reporter; however, TNF- $\alpha$ failed to activate the HIV-1-LTR $(\Delta \kappa \mathrm{\kappa})$-luc reporter (Fig. 5A). Similarly, quercetin induced $\sim 1.56$-fold upregulation of the HIV-1-LTR-luc reporter, $\sim 1.53$-fold upregulation of the HIV-1-LTR ( $\triangle \mathrm{AP}-1)$-luc and $\sim 1.58$-fold upregulation of the HIV-1-LTR $(\triangle \mathrm{SP} 1)$-luc reporters, whereas it failed to activate the HIV-1-LTR $(\Delta \kappa \mathrm{B})$-luc reporter. These results indicated that NF- $\mathrm{KB}$ transcription factors may serve an important role in quercetin-mediated activation of latent HIV-1 LTR expression. In order to further confirm the involvement of the NF- $\kappa \mathrm{B}$ signaling pathway in quercetin-mediated activation of latent HIV-1 LTR expression, an EMSA was performed to assess whether quercetin treatment was a sufficient stimulus for NF- $\mathrm{NB}$ nuclear translocation and DNA binding. Nuclear extracts from C11 cells treated with

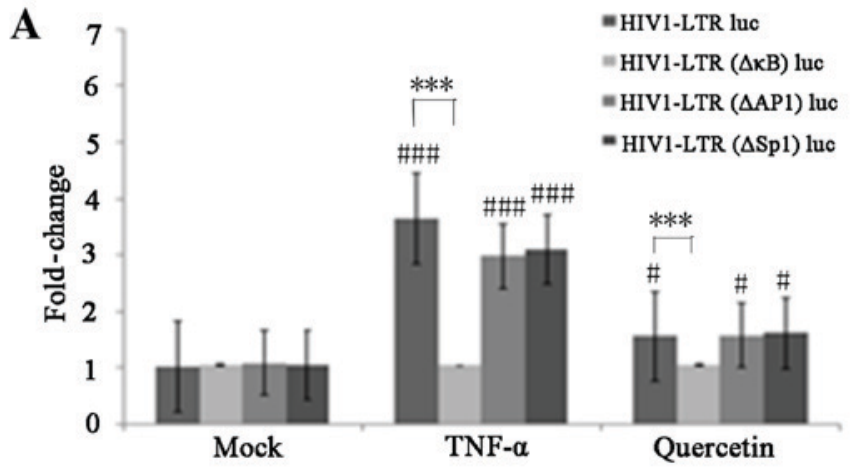

B

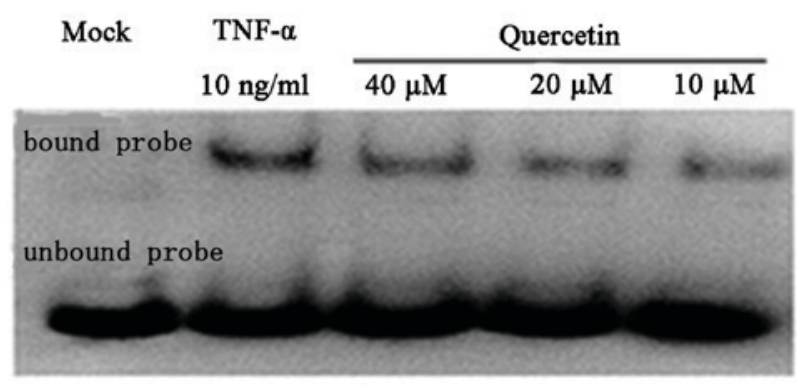

Figure 5. Quercetin activates the HIV-1 LTR via induction of NF- $\kappa B$. (A) HEK 293T cells were transfected with HIV1-LTR luc, HIV1-LTR $(\Delta \kappa \mathrm{B})$ luc, HIV1-LTR $(\Delta \mathrm{AP}-1)$ luc and HIV1-LTR $(\Delta \mathrm{SP} 1)$ luc. At $24 \mathrm{~h}$ post-transfection, the cells were mock-treated or treated with quercetin $(20 \mu \mathrm{M})$ or TNF- $\alpha(10 \mathrm{ng} / \mathrm{ml})$. Luc activity was measured after $48 \mathrm{~h}$ of treatment. Data are presented as the mean \pm standard deviation. (B) Quercetin stimulates nuclear NF- $\kappa \mathrm{B}$ DNA binding. C11 cells were treated with quercetin $(10,20$ and $40 \mu \mathrm{M})$ for $3 \mathrm{~h}$ or with TNF- $\alpha(10 \mathrm{ng} / \mathrm{ml})$ for $30 \mathrm{~min}$. Nuclear extracts were isolated and subject to an electrophoretic mobility shift assay with biotin-labeled NF- $\kappa B$ enhancer DNA probes. ${ }^{\#} \mathrm{P}<0.05$ and ${ }^{\# \# \#} \mathrm{P}<0.001$ vs. mock treated cells; ${ }^{* * *} \mathrm{P}<0.001$ vs. HIV1-LTR $(\Delta \kappa \mathrm{B})$ luc-infected cells. HIV-1,

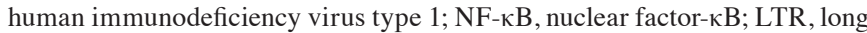
terminal repeat; luc, luciferase; AP-1, activator protein-1; SP1, specificity protein 1 ; TNF- $\alpha$, tumor necrosis factor- $\alpha$.

quercetin or TNF- $\alpha$ were incubated with biotin-labeled NF- $\mathrm{KB}$ enhancer oligonucleotides. The results demonstrated that quercetin increased the translocation of NF- $\mathrm{KB}$ to the nucleus in a concentration-dependent manner (Fig. 5B). These results provided further evidence to suggest that quercetin-mediated regulation of HIV-1 gene expression may occur via the NF- $\kappa \mathrm{B}$ signaling pathway.

\section{Discussion}

Although recent studies investigating the clinical consequences of latent HIV-1 infection have made progress, the persistence of the latent reservoir of integrated HIV-1 proviruses in resting $\mathrm{CD} 4^{+} \mathrm{T}$ cells is a major obstacle for viral eradication (40). Therefore the development of an effective treatment for HIV-1 infection remains a challenge (41). Reactivation of the latent provirus in patients receiving HAART is a promising strategy for the depletion of the latent viral reservoir (42). In order to achieve this aim, Katlama et al (43) proposed a three-tiered strategy to reactivate the latent cells and eliminate viral reservoirs. The first and most important step is to reactivate the expression of the latent HIV-1 provirus. Therefore, various studies have focused on agents that target different mechanisms of HIV-1 latency, including VPA, TNF- $\alpha$ and prostratin (44). 
However, the toxicity and ineffectiveness of these agents in clinical trials and the necessity for prolonged treatment limit the applications of these agents (45). It is thought that treatment with a combination of agents may be less toxic and more effective (46). Therefore, the identification of improved treatment combinations that demonstrate increased specificity is required.

Quercetin, is a flavonol that is used in the treatment of allergies, asthma, bacterial infections, arthritis, gout, eye disorders, hypertension and neurodegenerative disorders (27). Quercetin has demonstrated the ability to treat HIV-1 as a drug in HAART (47); however, there is limited information regarding the effect of quercetin on HIV-1 latency. Therefore, the present study used a simple in vitro model of latent HIV-1 infection in order to investigate whether quercetin reactivates latently infected C11 cells. A plasmid vector encoding GFP under the control of the HIV-1 LTR was transfected into C11 cells, and used as a marker of HIV-1 expression. The expression of the HIV-1 LTR was detected by fluorescence microscopy and flow cytometry (30). The results demonstrated that quercetin effectively reactivated HIV-1 latency and exhibited low toxicity in $\mathrm{C} 11$ cells at concentrations $\leq 20 \mu \mathrm{M}$. In addition, the results demonstrated that latent HIV-1 replication was activated by quercetin in a time- and concentration-dependent manner.

Compared with prostrotin and additional activators, the effect of quercetin alone on HIV-1 reactivation is weak; however, quercetin is less toxic to cells $(37,46)$. Therefore, the current study investigated whether synergistic activation of HIV-1 occurred when quercetin was combined with VPA or prostratin in C11 cells. VPA and prostratin were selected as they demonstrate a potent effect on the reactivation of infection in latently infected cell lines and ex vivo primary cells $(48,49)$. The results of the present study demonstrated that co-treatment with quercetin plus VPA or quercetin plus prostratin induced HIV-1 expression in a higher percentage of C11 cells when compared with each activator alone. These results indicated that quercetin combined with VPA or prostratin may lead to synergistic reactivation of HIV-1 production at a lower concentration in $\mathrm{C} 11$ cells, therefore, lower concentrations of these agents may be used to reactivate latent HIV-1 cells. These results are consistent with previous studies demonstrating that co-treatment with an NK- $\mathrm{B}$ inducer and histone deacetylase inhibitor synergistically increased the proportion of J-Lat cells displaying GFP fluorescence when compared with treatment with each compound in isolation $(36,50)$, and one study reported that prostratin synergizes with other activators to promote activation of latent HIV via NF- $\kappa \mathrm{B}$ (51).

Viral and cellular transcription factors with binding sites in the HIV-1 LTR serve an important role in the expression of latent HIV-1. The HIV-1 LTR contains several DNA-binding sites for various cellular transcription factors, including NFAT, AP-1, SP1, NF- $\mathrm{B}$, lymphoid enhancer binding factor 1 , COUP transcription factor 2, ETS proto-oncogene 1 and upstream stimulatory factor $(52,53)$. Of these, $N F-\kappa B$ serves an important role in the reactivation pathway of latent HIV-1. A previous study reported that quercetin inhibited inflammation associated with $\mathrm{NF}-\kappa \mathrm{B}$ in specific cell lines (54). Therefore, the present study investigated whether the NF- $\kappa \mathrm{B}$ signaling pathway may be involved in the quercetin-mediated activation of the latent HIV-1 LTR in C11 cells. The results indicated that quercetin effectively reactivated the wild-type HIV-1 LTR-luc, the HIV-LTR ( $\triangle \mathrm{AP}-1)$-luc and the HIV-LTR ( $\Delta$ SP1)-luc reporters, whereas, it failed to activate the LTR reporter lacking the $\kappa \mathrm{B}$ enhancers. In addition, the results indicated that nuclear translocation of $\mathrm{NF}-\kappa \mathrm{B}$ was induced by quercetin in a concentration-dependent manner as determined by EMSA analysis. Together, the results of the current study indicate that quercetin may activate HIV-1 gene expression via the $\mathrm{NF}-\kappa \mathrm{B}$ signaling pathway.

In conclusion, the HIV-1 viral reservoir is a major obstacle to the eradication of the provirus in patients receiving HAART. A current therapeutic strategy, termed 'shock-and-kill', has been proposed as a promising solution to eradicate HIV-1 reservoirs in the presence of HAART. For this therapy to be successful, the primary and most important aim is to identify a method of inducing latent HIV-1 gene expression. Due to the limitations of ineffectiveness and toxicity, the agents that have previously been investigated have failed in the clinic (44). Therefore, the identification of agents that exhibit lower toxicity is required. The current study demonstrated that quercetin is a potent activator of HIV-1 latency that lacks obvious cytotoxicity and may function via the $\mathrm{NF}-\kappa \mathrm{B}$ signaling pathway. Notably, the results indicated that quercetin synergizes with VPA or prostratin in the induction of HIV-1 transcription. In addition, a previous study demonstrated that the majority of agents that have been identified, and that do not cause global $\mathrm{T}$ cell activation, are ineffective in the clinic (44). Therefore, it is important to identify agents that may reactivate latent HIV-1 without global T cell activation, The results of the current study suggest that quercetin may meet these criteria. However, this study employed an in vitro model of HIV-1 latency, therefore further investigation into the effects of quercetin in a wider population of latent HIV-1 infected cells from HAART-treated patients will be required to explore this agent as a potential drug candidate. In addition, further investigation as to whether quercetin may lead to global $\mathrm{T}$ cell activation should be performed.

\section{Acknowledgements}

The present study was supported by the Shanghai Scientific Research Plan Project (grant no. 14401902000) and the National Natural Science Foundation of China (grant no. 31501032)

\section{References}

1. Davey RT Jr, Bhat N, Yoder C, Chun TW, Metcalf JA, Dewar R, Natarajan V, Lempicki RA, Adelsberger JW, Miller KD, et al: HIV-1 and T cell dynamics after interruption of highly active antiretroviral therapy (HAART) in patients with a history of sustained viral suppression. Proc Natl Acad Sci USA 96: 15109-15114, 1999.

2. Dahabieh MS, Battivelli E and Verdin E: Understanding HIV latency: The road to an HIV cure. Annu Rev Med 66: 407-421, 2015.

3. Lohse N, Hansen AB, Pedersen G, Kronborg G, Gerstoft J, Sørensen HT, Vaeth M and Obel N: Survival of persons with and without HIV infection in Denmark, 1995-2005. Ann Intern Med 146: 87-95, 2007.

4. Finzi D, Hermankova M, Pierson T, Carruth LM, Buck C, Chaisson RE, Quinn TC, Chadwick K, Margolick J, Brookmeyer R, et al: Identification of a reservoir for HIV-1 in patients on highly active antiretroviral therapy. Science 278: 1295-3100, 1997. 
5. Wong JK, Hezareh M, Günthard HF, Havlir DV, Ignacio CC, Spina CA and Richman DD: Recovery of replication-competent HIV despite prolonged suppression of plasma viremia. Science 278: 1291-1295, 1997.

6. Strain MC, Little SJ, Daar ES, Havlir DV, Gunthard HF, Lam RY, Daly OA, Nguyen J, Ignacio CC, Spina CA, et al: Effect of treatment, during primary infection, on establishment and clearance of cellular reservoirs of HIV-1. J Infect Dis 191: 1410-1418, 2005.

7. Siliciano JD, Kajdas J, Finzi D, Quinn TC, Chadwick K, Margolick JB, Kovacs C, Gange SJ and Siliciano RF: Long-term follow-up studies confirm the stability of the latent reservoir for HIV-1 in resting CD4+ ${ }^{+}$cells. Nat Med 9: 727-728, 2003.

8. Mehla R, Bivalkar-Mehla S, Zhang R, Handy I, Albrecht H, Giri S, Nagarkatti P, Nagarkatti M and Chauhan A: Bryostatin modulates latent HIV-1 infection via PKC and AMPK signaling but inhibits acute infection in a receptor independent manner. PLoS One 5: e11160, 2010.

9. Han Y, Lin YB, An W, Xu J, Yang HC, O'Connell K, Dordai D, Boeke JD, Siliciano JD and Siliciano RF: Orientation-dependent regulation of integrated HIV-1 expression by host gene transcriptional readthrough. Cell Host Microbe 4: 134-146, 2008.

10. Shan L, Yang HC, Rabi SA, Bravo HC, Shroff NS, Irizarry RA, Zhang H, Margolick JB, Siliciano JD and Siliciano RF: Influence of host gene transcription level and orientation on HIV-1 latency in a primary-cell model. J Virol 85: 5384-5393, 2011.

11. Lenasi T, Contreras X and Peterlin BM: Transcriptional interference antagonizes proviral gene expression to promote HIV latency. Cell Host Microbe 4: 123-133, 2008.

12. Mbonye U and Karn J: Control of HIV latency by epigenetic and non-epigenetic mechanisms. Curr HIV Res 9: 554-567, 2011.

13. Margolis DM, Garcia JV, Hazuda DJ and Haynes BF: Latency reversal and viral clearance to cure HIV-1. Science 353: aaf6517, 2016.

14. Del Prete GQ, Shoemaker R, Oswald K, Lara A, Trubey CM, Fast R, Schneider DK, Kiser R, Coalter V, Wiles A, et al: Effect of suberoylanilide hydroxamic Acid (SAHA) administration on the residual virus pool in a model of combination antiretroviral therapy-mediated suppression in SIVmac239-infected indian rhesus macaques. Antimicrob Agents Chemother 58: 6790-6806, 2014.

15. Mazzoccoli G, Longhitano C and Vinciguerra M: Cardio-hepatic metabolic derangements and valproic acid. Curr Clin Pharmacol 9: 165-170, 2014.

16. Huber K, Doyon G, Plaks J, Fyne E, Mellors JW and Sluis-Cremer N: Inhibitors of histone deacetylases: Correlation between isoform specificity and reactivation of HIV type 1 (HIV-1) from latently infected cells. J Biol Chem 286 22211-22218, 2011.

17. Rasmussen TA, Schmeltz Søgaard O, Brinkmann C, Wightman F Lewin SR, Melchjorsen J, Dinarello C, Østergaard L and Tolstrup M: Comparison of HDAC inhibitors in clinical development: Effect on HIV production in latently infected cells and T-cell activation. Hum Vaccin Immunother 9: 993-1001, 2013.

18. Hao Y, Zhang Y, Zhou X, Qu X, Wang P, Liu S, Lu D and Zhu H: Selective histonedeacetylase inhibitor M344 intervenes in HIV-1 latency through increasing histone acetylation and activation of NF-kappaB. PLoS One 7: e48832, 2012.

19. Folks TM, Clouse KA, Justement J, Rabson A, Duh E, Kehrl JH and Fauci AS: Tumor necrosis factor alpha induces expression of human immunodeficiency virus in a chronically infected T-cell clone. Proc Natl Acad Sci USA 86: 2365-2368, 1989.

20. Wang P, Qu X, Wang X, Liu L, Zhu X, Zeng H and Zhu H: As2O3 synergistically reactivate latent HIV-1 by induction of NF- $\kappa B$ Antiviral Res 100: 688-697, 2013.

21. Fernandez G and Zeichner SL: Cell line-dependent variability in HIV activation employing DNMT inhibitors. Virol J 7: 266 , 2010.

22. Imai $\mathrm{K}$, Togami $\mathrm{H}$ and Okamoto $\mathrm{T}$ : Involvement of histone $\mathrm{H} 3$ lysine 9 (H3K9) methyltransferase G9a in the maintenance of HIV-1 latency and its reactivation by BIX01294. J Biol Chem 285: 16538-16545, 2010.

23. Williams SA, Chen LF, Kwon H, Fenard D, Bisgrove D, Verdin E and Greene WC: Prostratin antagonizes HIV latency by activating NF-kappaB. J Biol Chem 279: 42008-42017, 2004

24. Vlach J and Pitha PM: Hexamethylene bisacetamide activates the human immunodeficiency virus type 1 provirus by an NF-kappa B-independent mechanism. J Gen Virol 74: 2401-2408, 1993.

25. Xing S, Bullen CK, Shroff NS, Shan L, Yang HC, Manucci JL, Bhat S, Zhang H, Margolick JB, Quinn TC, et al: Disulfiram reactivates latent $\mathrm{HIV}-1$ in a Bcl-2-transduced primary $\mathrm{CD}^{+} \mathrm{T}$ cell model without inducing global T cell activation. J Virol 85: 6060-6064, 2011.
26. Larson AJ, Symons JD and Jalili T: Therapeutic potential of quercetin to decrease blood pressure: Review of efficacy and mechanisms. Adv Nutr 3: 39-46, 2012.

27. Fesen MR, Kohn KW, Leteurtre F and Pommier Y: Inhibitors of human immunodeficiency virus integrase. Proc Natl Acad Sci USA 90: 2399-2403, 1993.

28. Tanaka R, Tsujii H, Yamada T, Kajimoto T, Amano F, Hasegawa J, Hamashima Y, Node M, Katoh K and Takebe Y: Novel 3alpha-m ethoxyserrat-14-en-21beta-ol (PJ-1) and 3beta-methoxyserrat-14en-21beta-ol (PJ-2)-curcumin, kojic acid, quercetin, and baicalein conjugates as HIV agents. Bioorg Med Chem 17: 5238-5246, 2009.

29. Ying H, Zhang Y, Zhou X, Qu X, Wang P, Liu S, Lu D and Zhu H: Selective histonedeacetylase inhibitor M344 intervenes in HIV-1 latency through increasing histone acetylation and activation of NF-kappaB. PLoS One 7: e48832, 2012.

30. Wang P, Qu X, Wang X, Liu L, Zhu X, Zeng H and Zhu H: As2O3 synergistically reactivate latent HIV-1 by induction of NF- $\kappa \mathrm{B}$. Antiviral Res 100: 688-697, 2013.

31. Ding D, Qu X, Li L, Zhou X, Liu S, Lin S, Wang P, Liu S, Kong C, Wang X, et al: Involvement of histone methyltransferase GLP in HIV-1 latency through catalysis of H3K9 dimethylation. Virology 440: 182-189, 2013.

32. Kutner RH, Zhang XY and Reiser J: Production, concentration and titration of pseudotyped HIV-1-based lentiviral vectors. Nat Protoc 4: 495-505, 2009.

33. Lin S, Zhang Y, Ying $\mathrm{H}$ and Zhu $\mathrm{H}$ : HIV-1 reactivation induced by apicidin involves histone modification in latently infected cells. Curr HIV Res 9: 202-208, 2011.

34. Wang FX, Xu Y, Sullivan J, Souder E, Argyris EG, Acheampong EA, Fisher J, Sierra M, Thomson MM, Najera R, et al: IL-7 is a potent and proviral strain-specific inducer of latent HIV-1 cellular reservoirs of infected individuals on virally suppressive HAART. J Clin Invest 115: 128-137, 2005.

35. Bren GD, Whitman J, Cummins N, Shepard B, Rizza SA, Trushin SA and Badley AD: Infected cell killing by HIV-1 protease promotes NF-kappaB dependent HIV-1 replication. PLoS One 3: e2112, 2008.

36. Lilling G, Elena N, Sidi Y and Bakhanashvili M: p53-associated $3^{\prime} \rightarrow 5$ ' exonuclease activity in nuclear and cytoplasmic compartments of cells. Oncogene 22: 233-245, 2003.

37. Kulkosky J, Culnan DM, Roman J, Dornadula G, Schnell M, Boyd MR and Pomerantz RJ: Prostratin: Activation of latent HIV-1 expression suggests a potential inductive adjuvant therapy for HAART. Blood 98: 3006-3015, 2001.

38. Reuse S, Calao M, Kabeya K, Guiguen A, Gatot JS, Quivy V, Vanhulle C, Lamine A, Vaira D, Demonte D, et al: Synergistic activation of HIV-1 expression by deacetylase inhibitors and prostratin: Implications for treatment of latent infection. PLoS One 4: e6093, 2009

39. Victoriano AF and Okamoto T: Transcriptional control of HIV replication by multiple modulators and their implication for a novel antiviral therapy. AIDS Res Hum Retroviruses 28: 125-138, 2012.

40. Persaud D, Zhou Y, Siliciano JM and Siliciano RF: Latency in human immunodeficiency virus Type 1 infection: No easy answers. J Virol 77: 1659-1665, 2003.

41. Shan L and Siliciano RF: From reactivation of latent HIV-1 to elimination of the latent reservoir: The presence of multiple barriers to viral eradication. Bioessays 35: 544-552, 2013.

42. Shishido T, Wolschendorf F, Duverger A, Wagner F, Kappes J, Jones J and Kutsch O: Selected drugs with reported secondary cell-differentiating capacity prime latent HIV-1 infection for reactivation. J Virol 86: 9055-9069, 2012.

43. Katlama C, Deeks SG, Autran B, Martinez-Picado J, van Lunzen J, Rouzioux C, Miller M, Vella S, Schmitz JE, Ahlers J, et al: Barriers to a cure for HIV: New ways to target and eradicate HIV-1 reservoirs. Lancet 381: 2109-2117, 2013.

44. Rasmussen TA and Lewin SR: Shocking HIV out of hiding: Where are we with clinical trials of latency reversing agents? Curr Opin HIV AIDS 11: 394-401, 2016.

45. Xing S and Siliciano RF: Targeting HIV latency: Pharmacologic strategies toward eradication. Drug Discov Today 18: 541-551, 2013.

46. Darcis G, Van DB and Van LC. HIV latency: should we shock or lock? Trends Immunol 38: 217-22,8 2017.

47. Nair MPN, Saiyed ZM, Gandhi NH and Ramchand CN: The Flavonoid, Quercetin, Inhibits HIV-1 Infection in normal peripheral blood mononuclear cells. Am J Infect Dis 5: 135-141, 2009. 
48. Moog C, Kuntz-Simon G, Caussin-Schwemling C and Obert G: Sodium valproate, an anticonvulsant drug, stimulates human immunodeficiency virus type 1 replication independently of glutathione levels. J Gen Virol 77: 1993-1999, 1996.

49. Hezareh M: Prostratin as a new therapeutic agent targeting HIV viral reservoirs. Drug News Perspect 18: 496-500, 2005.

50. Márquez N, Calzado MA, Sánchez-Duffhues G, Pérez M, Minassi A, Pagani A, Appendino G, Diaz L, MuñozFernández MA and Muñoz E: Differential effects of phorbol-13-monoesters on human immunodeficiency virus reactivation. Biochem Pharmacol 75: 1370-1380, 2008.

51. Chan JK, Bhattacharyya D, Lassen KG, Ruelas D and Greene WC: Calcium/calcineurin synergizes with prostratin to promote NF-кB dependent activation of latent HIV. PLoS One 8: e77749, 2013
52. Suñé C and García-Blanco MA: Sp1 transcription factor is required for in vitro basal and Tat-activated transcription from the human immunodeficiency virus type 1 long terminal repeat. J Virol 69: 6572-6576, 1995.

53. Perkins ND, Edwards NL, Duckett CS, Agranoff AB, Schmid RM and Nabel GJ: A cooperative interaction between NF-kappaB and $\mathrm{Spl}$ is required for HIV-1 enhancer activation. EMBO J 12: 3551-3558, 1993

54. Indra MR, Karyono S, Ratnawati R and Malik SG: Quercetin suppresses inflammation by reducing ERK1/2 phosphorylation and NF kappaB activation in Leptin-induced human umbilical vein endothelial cells (HUVECs). BMC Res Notes 6: 275, 2013. 